\title{
Estimation of environment-induced crack growth rate as a function of stress intensity factors generated during slow strain rate testing of aluminum alloys
} Dol:

10.1515/corrrev-2019-0031

\section{Document Version \\ Accepted author manuscript}

Link to publication record in Manchester Research Explorer

Citation for published version (APA):

Burnett, T., \& Holroyd, N. (2019). Estimation of environment-induced crack growth rate as a function of stress intensity factors generated during slow strain rate testing of aluminum alloys. Corrosion Reviews.

https://doi.org/10.1515/corrrev-2019-0031

\section{Published in:}

Corrosion Reviews

\section{Citing this paper}

Please note that where the full-text provided on Manchester Research Explorer is the Author Accepted Manuscript or Proof version this may differ from the final Published version. If citing, it is advised that you check and use the publisher's definitive version.

\section{General rights}

Copyright and moral rights for the publications made accessible in the Research Explorer are retained by the authors and/or other copyright owners and it is a condition of accessing publications that users recognise and abide by the legal requirements associated with these rights.

\section{Takedown policy}

If you believe that this document breaches copyright please refer to the University of Manchester's Takedown Procedures [http://man.ac.uk/04Y6Bo] or contact uml.scholarlycommunications@manchester.ac.uk providing relevant details, so we can investigate your claim.

\section{OPEN ACCESS}


N J Henry Holroyd ${ }^{1,2}$, Timothy L Burnett ${ }^{2}$, Benjamin C Palmer ${ }^{1}$

and John J Lewandowski ${ }^{1}$

Estimation of environment-induced crack growth rate as a function of stress intensity factors generated during slow strain rate testing of aluminum alloys

\footnotetext{
${ }^{1}$ Department of Materials Science \& Engineering, Case Western Reserve University, Cleveland, Ohio, USA

${ }^{2}$ Henry Moseley X-ray Imaging Facility, School of Materials, The University of Manchester, Manchester, M13 9PL, UK
}

\section{Abstract:}

In this contribution we introduce a simple approach to quickly estimate the environmentinduced crack velocity (CV) as a function of the calculated applied stress intensity factor (K) developed during the slow strain rate testing of aluminum alloys exposed to aqueous or humidair type environments. The CV-K behavior for a commercial aluminum-magnesium alloy, AA5083-H131, sensitized and pre-exposed to a $0.6 \mathrm{M} \mathrm{NaCl}$ solution has been estimated from slow strain rate test data. The predicted threshold $\mathrm{K}$ and crack velocities match recently published data for the same alloy in similarly sensitized conditions where the CV-K data was obtained using state-of-the-art fracture mechanics based testing.

Keywords: aluminum alloys; corrosion; fracture; stress corrosion cracking

\section{Introduction}

Environment-induced cracking (EIC) in commercial higher strength aluminum alloys (Al-Zn-Mg$\mathrm{Cu}, 7 x x x$ series and Al-Cu-Mg, 2000 series) has been assessed in mechanically loaded precracked test specimens exposed to various environments since the late 1960's (Mulherin, 1967; McEvily et al., 1967; Hyatt, 1969). Early findings from these bolt-loaded double cantilever beam (DCB) test specimens (Hyatt, 1969) are summarized elsewhere, in terms of an estimated crack growth rate (CV) as a function of the applied stress intensity factor (K), commonly referred to as CV-K curves (Hyatt, 1969; Spiedel and Hyatt, 1972; Spiedel, 1975). Published data for Al-Zn-Mg$\mathrm{Cu}, 7 x x x$ series alloys has been recently reviewed in detailed elsewhere (Holroyd \& Scamans, 2013).

Constant-displacement, static loading based test methods, such a bolt-loaded DCB testing, while providing experimentally simple and potentially relatively low-cost options are often compromised by a lack of reproducibility (Dietzel, 2000) and very long test times (e.g.10,000 hr) to obtain threshold stress intensity factors, $\mathrm{K}_{\mathrm{IScc}}$. In addition, experimental issues associated with out-of-plane crack growth or crack-branching (Domak, 1990) and/or crack corrosion 
product wedging generating local stresses (Schra \& Faber, 1981; McNaughtan et al., 2003) can potentially invalidate $\mathrm{K}_{1 \mathrm{scc}}$ values associated with crack arrest under decreasing $\mathrm{K}$.

Rising-displacement based tests methods, developed over the last 25 years or so, while potentially considerably shortening test times needed to generate threshold data have their own potential issues, including a) validity of output data is strongly dependent on the selection of an appropriate displacement rate (Dietzel, 2000; Dietzel \& Mueller-Roos, 2001) which must be independently verified on a case-by-case basis, typically using fractographic evidence (Dietzel, 2000) and b) test methods require state-of-the-art fracture mechanics based testing equipment and thereby no longer offer a 'low-cost' test option.

Usage of CV-K data to formally assess/quantify the potential susceptibility of commercial aluminum alloys to EIC with respect to service performance remains limited, despite detailed evaluations of the approach (Sprowls et al., 1973 \& 1976; Kaufman et al., 1976; Domack, 1990; Dietzel, 1999) and publication of Standardized Test Methods in the US (ASTM, 1995) and Europe (ISO, 1998).

We present a low-cost approach to quickly estimate the CV-K relationship for the EIC of highstrength aluminum alloys. The method relies upon the acquisition of high-quality (low-noise) nominal stress as a function of the extension (relative plastic strain) promoted during the slow strain rate testing (SSRT) of conventional round-bar tensile samples. Prior to straining the specimens are given a pre-exposure treatment creating corrosion features to provide EIC crack initiation sites, free of any significant associated local stresses and limited local plasticity, unlike those associated with either fatigue pre-cracks or mechanical 'pop-in' cracks from a machined notch, as are typically generated in test specimens used to generated CV-K curves.

\section{Materials and Methods}

\subsection{Materials}

The alloy selected for testing was a commercial Al-Mg-Mn alloy, AA5083-H131, containing (wt\%) 4.46 Mg, 0.62 Mn, 0.12 Fe, 0.08Cr, 0.07 Si and 0.02 Zn (established using optical Emission Spectroscopy, a standard technique used in the aluminum industry for melt analysis of solidified samples) supplied in the form of $29-\mathrm{mm}$-thick rolled plate in the $\mathrm{H} 131$ condition. The alloy had a typical non-recrystallized fibrous microstructure with grain sizes of $150 \mu \mathrm{m}, 80 \mu \mathrm{m}$, and $35 \mu \mathrm{m}$ in the longitudinal (L), long-transverse (LT) and short-transverse (ST) directions, respectively (Seifi et al, 2016). A 0.2\% yield strength of $270 \mathrm{MPa}$ and ultimate tensile strength (UTS) of $375 \mathrm{MPa}$ were obtained for the ST direction when tested in air at $1 \times 10^{-3} / \mathrm{s}$, along with a $\mathrm{K}_{\mathrm{IC}}$ of $31 \mathrm{MNm}^{-3 / 2}$. 
For SSRT, smooth tensile specimens with a gauge length and diameter of 12.7 and $3.2 \mathrm{~mm}$, respectively, were machined with their major axis parallel to the short-transverse direction in order to maximize susceptibility to EIC.

\subsection{Sensitization, Pre-exposure and SSRT}

Alloy sensitization was conducted at $80{ }^{\circ} \mathrm{C}$ in an air-oven. $250 \mathrm{~h}$ sensitization at $80{ }^{\circ} \mathrm{C}$ resulted in a NAMLT value of $25-30 \mathrm{mg} / \mathrm{cm}^{2}$ (Seifi et al, 2016).

Ahead of pre-exposure to $0.6 \mathrm{M} \mathrm{NaCl}$, the tensile specimen gauge lengths were mechanically polished with 3/0 emery paper (soaked in paraffin oil) and ultrasonically degreased in acetone to ensure the generation of oil-free surfaces. After polishing, tensile samples were pre-exposed in $0.6 \mathrm{M} \mathrm{NaCl}$ at RT under full-immersion conditions for times up to 375 hours.

Immediately following the pre-exposure, SSRT tensile specimens were given a gentle rinse using a small volume of distilled water (DW), carefully dried with compressed air and within two minutes subjected to SSRT employing a nominal strain rate of $\sim 10^{-5} / \mathrm{s}$. The samples were exposed to either humid laboratory air (relative humidity, 50\%) or dry air, achieved by packing the test specimen in anhydrous magnesium perchlorate granules (Willard \& Smith, 1922). Surface films produced during pre-exposure were not removed prior to SSRT.

Fractured SSRT test specimens were cleaned in ethanol followed by examination in a FEI Quanta Scanning Electron Microscope in order to characterize fracture surface details, identify and map the various fracture modes and measure the linear depths of intergranular corrosion (IGC) and environment-induced cracking.

\subsection{Estimation of EIC growth rate/implied stress intensity factor during SSRT}

The method to estimate EIC depth and growth rates and the applied stress intensity factors generated during SSRT for tensile samples with a given sensitization/pre-exposure history, comprised of the following steps:

1) Calculation of nominal stress differentials as a function of the relative plastic strain for SSRT conducted in humid and dry air for the samples subjected to the same sensitization and preexposure treatments,

2) Assuming the stress differentials from 1 ) are directly relatable to an implied loss of loadbearing area attributable to EIC, calculate the EIC area developed during SSRT in humid air using the relationship: 
where Area is in $\mathrm{mm}^{2}$ and stress in $\mathrm{MPa}$

3) Estimate EIC crack depths as a function of relative strain (or time) during SSRT for various crack shapes using the 'Area of EIC' and an assumption EIC is predominantly associated with a single crack,

4) Calculate stress intensity factor (K) for the various crack shapes as a function of time by inputting the relevant stresses (taken from the SSRT data) and estimated crack depths (from 3 above) into published relationships for $\mathrm{K}$ as a function of load and crack depth (Sprowls et al., 1984; Stark \& Ibrahim, 1986, 1987; Carpinteri, 1992; Shih \& Chen, 2002) for cylindrical samples containing surface cracks.

5) Generate EIC crack velocity - stress intensity factor dependences (CV-K curves), using information gleaned from 1) to 4).

\section{Results}

\subsection{SSRT Data}

Engineering stress as a function of the \% relative plastic strain realized during SSRT conducted on as-received and sensitized AA5083-H131 samples strained in humid air (50\% RH) and dry air at a nominal strain rate of $10^{-5} / \mathrm{s}$ after pre-exposure to $0.6 \mathrm{M} \mathrm{NaCl}$ are provided in Figure 1 . The mechanical properties extracted, depths of intergranular corrosion (promoted during preexposure to $0.6 \mathrm{M} \mathrm{NaCl}$ ) and depths of EIC generated during SSRT reported earlier are shown in Table 1and further detailed background information on this SSRT is provided elsewhere (Holroyd et al., 2017).

Table 1: SSRT data for AA5083-H131 subjected to SSRT at a nominal strain rate of $10^{-5} / \mathrm{s}$ in either humid air (50\% $\mathrm{RH}$ ) or dry air.

\begin{tabular}{|c|c|c|c|c|c|c|c|c|}
\hline \multirow{2}{*}{$\begin{array}{c}\text { Test } \\
\#\end{array}$} & \multirow{2}{*}{$\begin{array}{c}\text { Sensitization } \\
\text { at } 80^{\circ} \mathrm{C}\end{array}$} & \multirow{2}{*}{$\begin{array}{c}\text { Exposure } \\
\text { in } 0.6 \mathrm{M} \\
\mathrm{NaCl}(\mathrm{hr})\end{array}$} & \multirow{2}{*}{$\begin{array}{c}\text { UTS } \\
\text { (MPa) }\end{array}$} & \multirow{2}{*}{$\begin{array}{c}\mathrm{YS} \\
(\mathrm{MPa})\end{array}$} & \multirow{2}{*}{$\begin{array}{c}\text { IGC } \\
\text { Depth } \\
(\mu \mathrm{m})\end{array}$} & \multicolumn{2}{|c|}{ Type-1 EIC } & \multirow{2}{*}{$\begin{array}{c}\text { SSRT } \\
\text { Conditions }\end{array}$} \\
\hline & & & & & & $\begin{array}{c}\mathrm{K}_{\mathrm{ISCC}} \\
\left(\mathrm{MNm}^{-3 / 2}\right)\end{array}$ & $\begin{array}{c}\text { Depth } \\
(\mu \mathrm{m})\end{array}$ & \\
\hline 4 & None & 375 & 329 & 257 & $65-90$ & 3.8 & 500 & Humid air \\
\hline 6 & None & 375 & 353 & 255 & 60 & - & - & Dry air \\
\hline 7 & 250 & 250 & 273 & 237 & 110 & 4.2 & 890 & Humid air \\
\hline 9 & 250 & 250 & 354 & 245 & 110 & - & - & Dry air \\
\hline
\end{tabular}




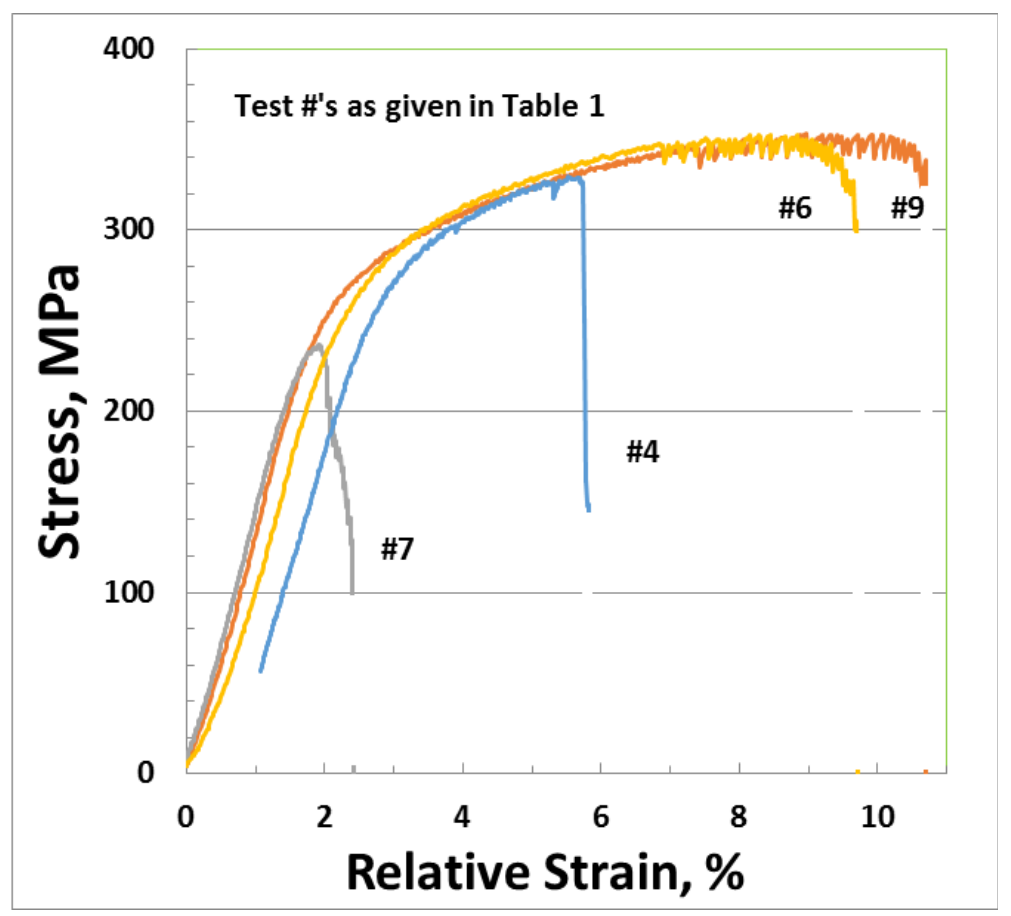

Figure 1: Representative engineering stress versus relative plastic strain curves for as-received and sensitized AA5083- $\mathrm{H} 131$ after pre-exposure to $0.6 \mathrm{M} \mathrm{NaCl}$ and then strained in either humid air ( $50 \% \mathrm{RH})$ or dry air at a nominal strain rate of $10^{-5} / \mathrm{s}$.

The relative extension data from the SSRT test's conducted in dry air (Test's \#6 and \#9) were shifted in the analysis so that the load - extension (time) curves during the later stages of elastic behavior overlap with equivalent test conducted in humid air (Test's \#4 and \#7), Figure 2.
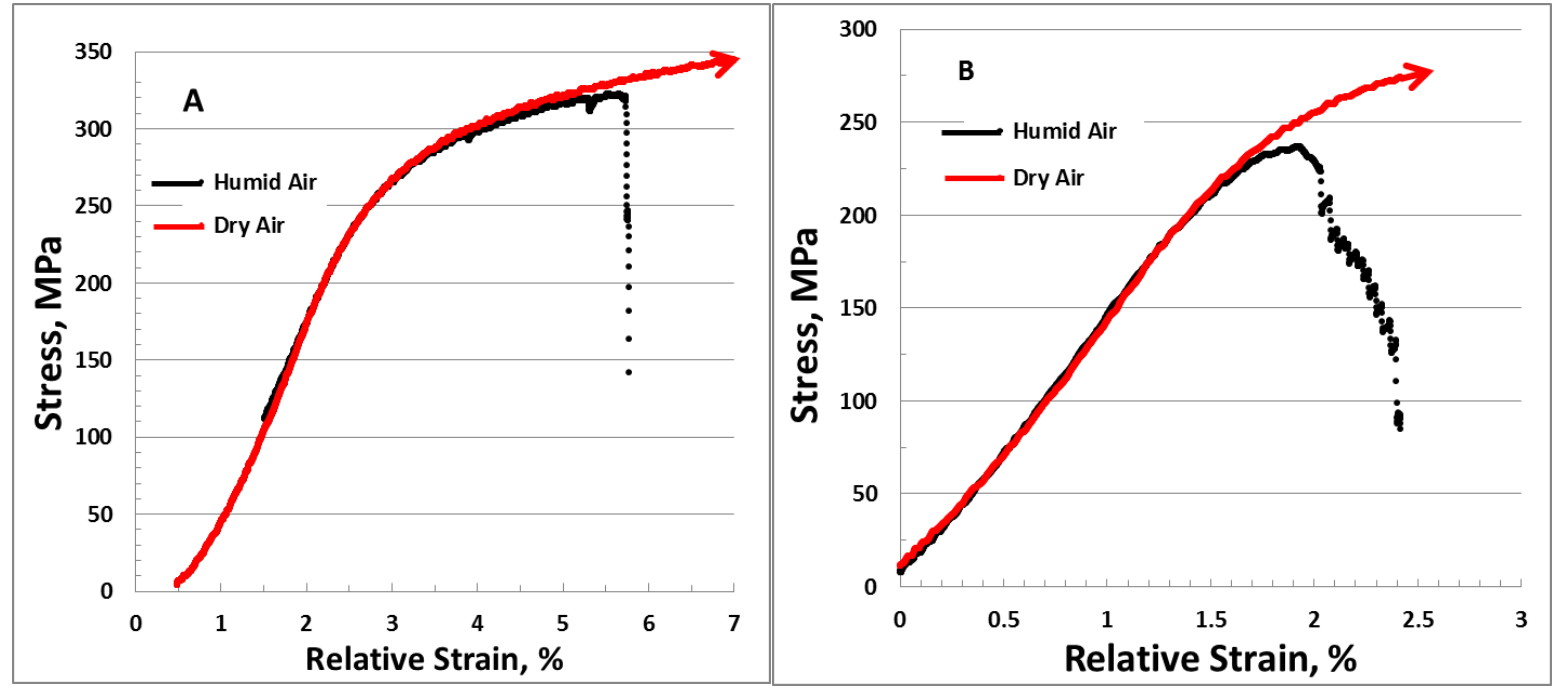
Figure 2: Comparison of the stress levels achieved in humid ( $50 \% \mathrm{RH})$ and dry air as function of the imposed extension during slow strain testing after pre-exposure to $0.6 \mathrm{M} \mathrm{NaCl}$. A) As-received AA5083-H131 $+375 \mathrm{hr}$ in $0.6 \mathrm{M} \mathrm{NaCl}$ and B) AA5083-H131 sensitized for $250 \mathrm{hr}$ at $80^{\circ} \mathrm{C}+250 \mathrm{hr}$ in $0.6 \mathrm{M} \mathrm{NaCl}$.

Stress level differentials as a function of the extension imposed for SSRT conducted in humid and dry air are calculated and based on an assumption these stress differentials are directly relatable to losses of load-bearing area (see Equation 1), they are used in the estimation of the implied area of EIC generated as a function of the \% relative strain. Estimated areas of EIC generated during the SSRT of AA5083-H131 in humid air (50\% RH) are presented in Figure 3, as a function of time following the imposed stress during straining exceeding around $200 \mathrm{MPa}$.

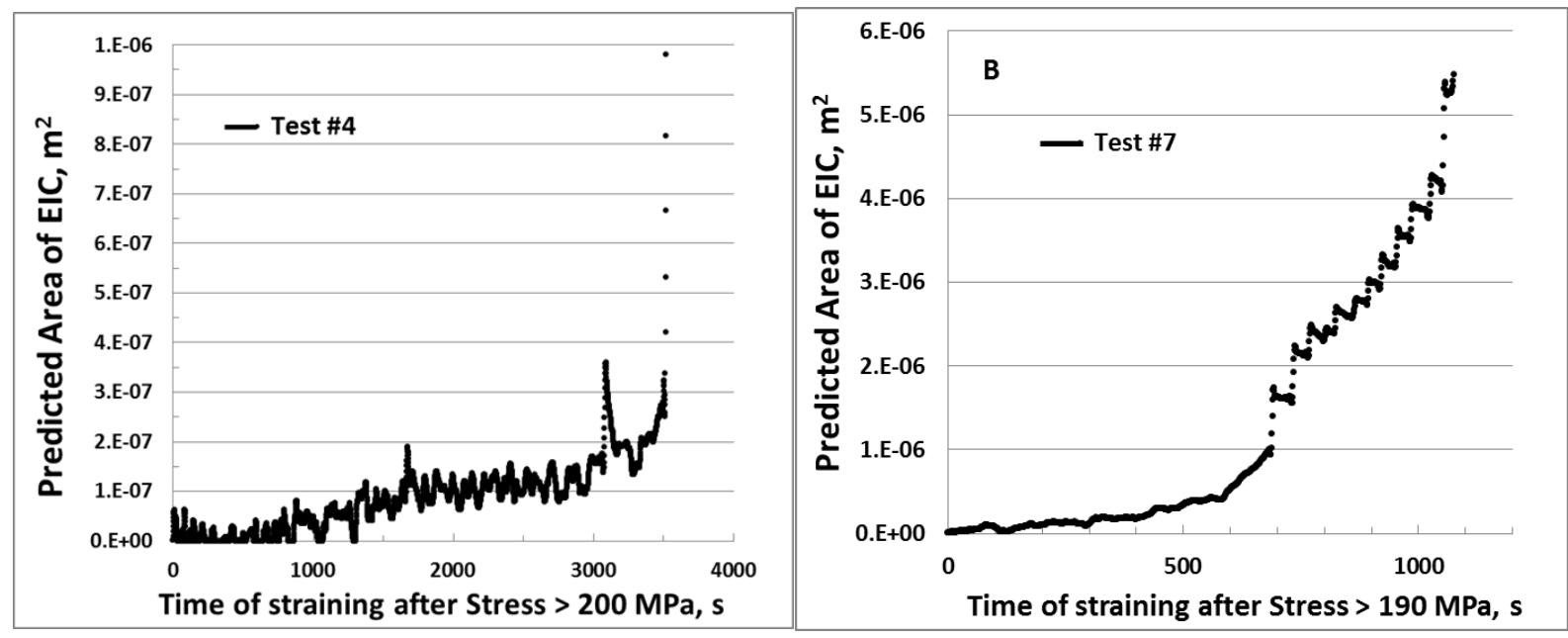

Figure 3: Estimated areas of EIC as a function of time during the SSRT of as-received (Test \#4) and sensitized (Test \#7) AA5083-H131 strained in humid air after pre-exposure to $0.6 \mathrm{M} \mathrm{NaCl}$.

Maximum EIC crack depths as a function of the cracked area can be estimated for various crack shapes, such as elliptical, chord or an external peripheral ring. Crack depths, are estimated assuming one main crack initiates from the external surface of the specimen with the results shown in Figure 4, where a 'half-penny' aspect ratio is assumed for an elliptical crack, as often is observed during the early stages of EIC (Holroyd \& Hardie, 1982; Burnett et al., 2017). 


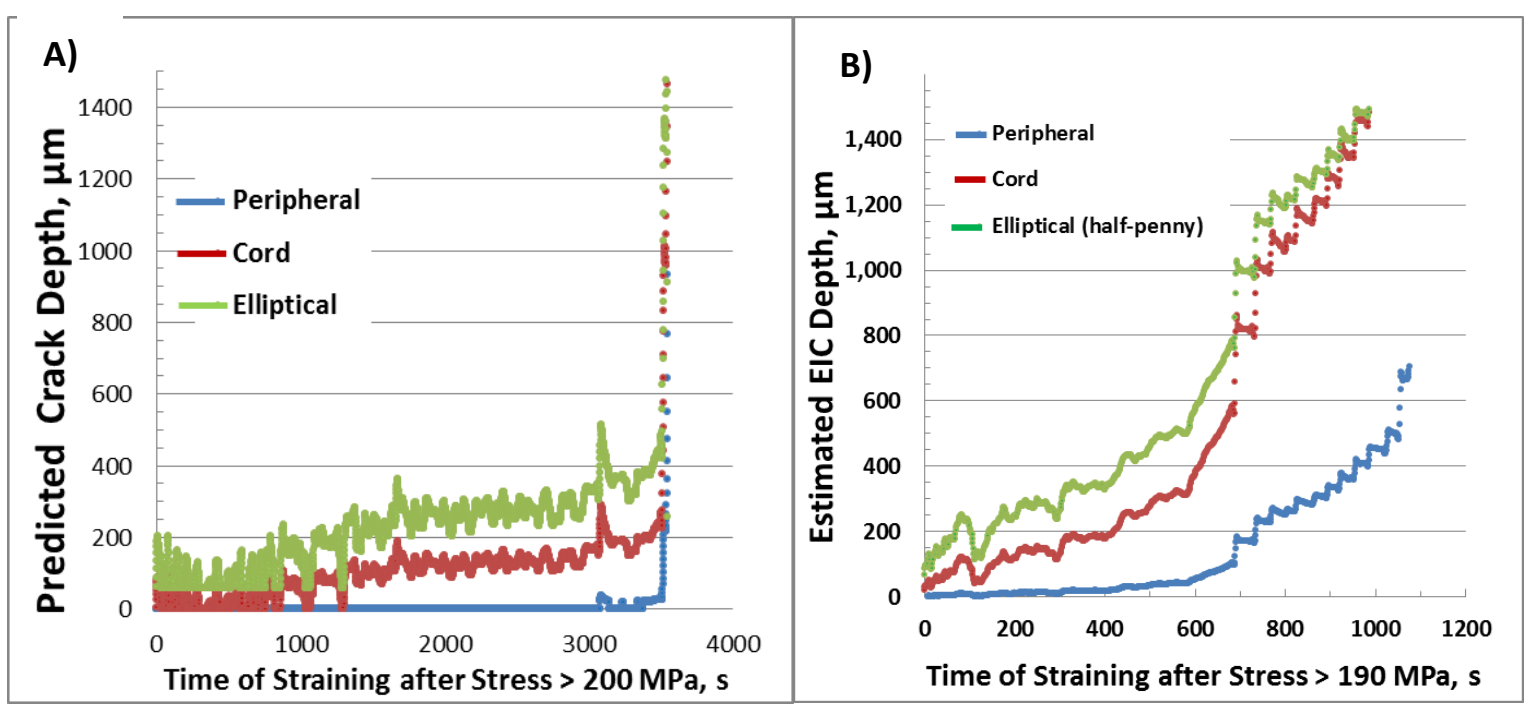

Figure 4: Estimated EIC depths for different crack geometries developed during the SSRT of as-received and sensitized AA5083-H131 pre-exposed to $0.6 \mathrm{M} \mathrm{NaCl}$ and strained in humid air at a nominal strain rate of $10^{-5} / \mathrm{s}$. A) As-received $+375 \mathrm{hr}$ pre-exposure to $0.6 \mathrm{M} \mathrm{NaCl}$ and B) Sensitized $250 \mathrm{hr} 80^{\circ} \mathrm{C}+250 \mathrm{hr}$ in $0.6 \mathrm{M} \mathrm{NaCl}$.

Having obtained the implied crack depths as a function of time for various crack shapes we can now calculate the associated crack growth rates as a function of time, Figure 5. Then using knowledge of the load applied during the SSRT as a function of time and assuming a crack profile we can calculate the local stress intensity factor, K, as a function of time, using published relationships for stressed round bars (Stark \& Ibrahim, 1986, 1987; Carpinteri, 1992; Shih \& Chen, 2002), Figure 6.

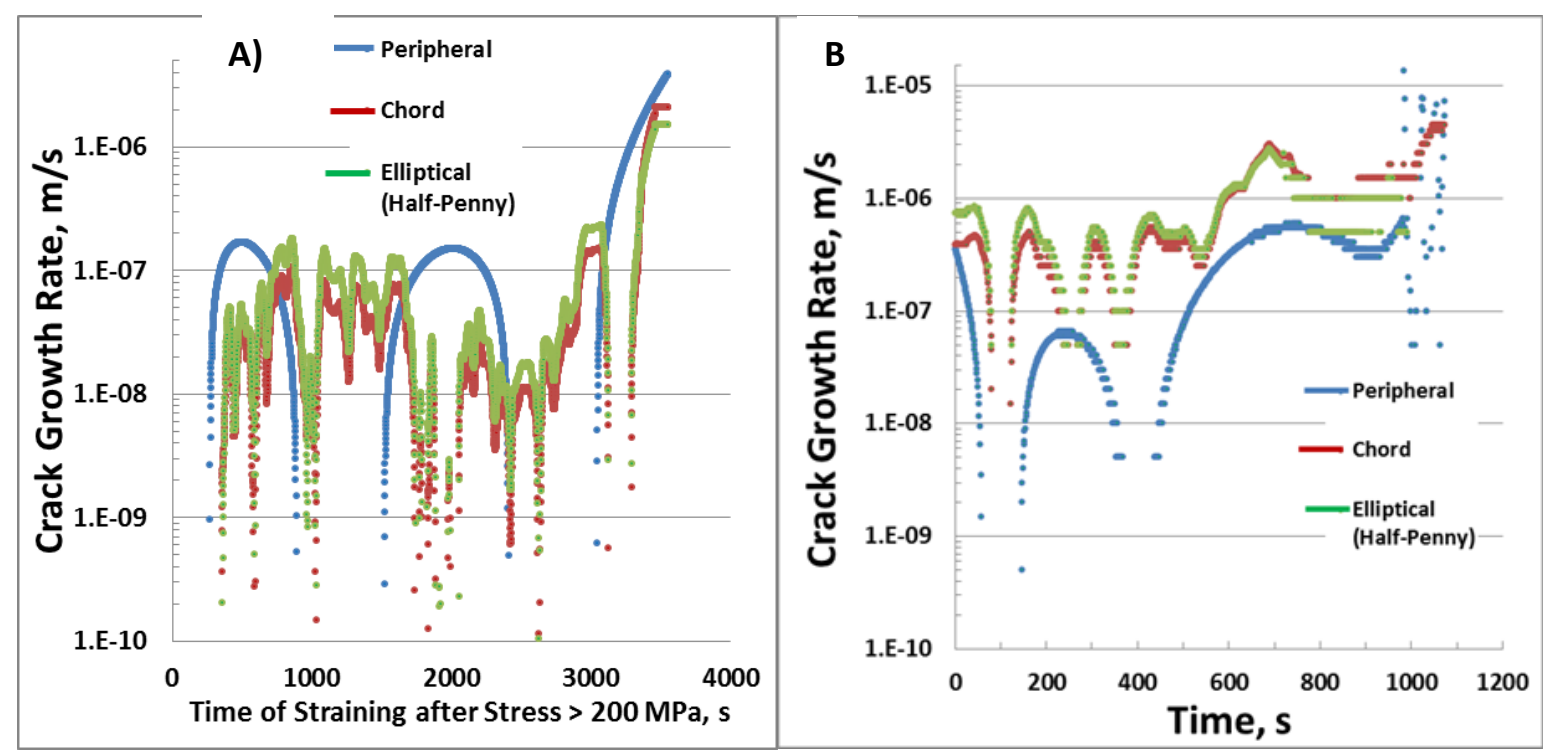

Figure 5: Predicted EIC growth rates for different crack geometries during the SSRT of as-received and sensitized AA5083- $\mathrm{H} 131$ pre-exposed to $0.6 \mathrm{M} \mathrm{NaCl}$ and strained in humid air at a nominal strain rate of $10^{-5} / \mathrm{s}$. A) As-received $+375 \mathrm{hr}$ pre-exposure to $0.6 \mathrm{M} \mathrm{NaCl}$ and B) Sensitized $250 \mathrm{hr} 80^{\circ} \mathrm{C}+250 \mathrm{hr}$ in $0.6 \mathrm{M} \mathrm{NaCl}$. 
A)
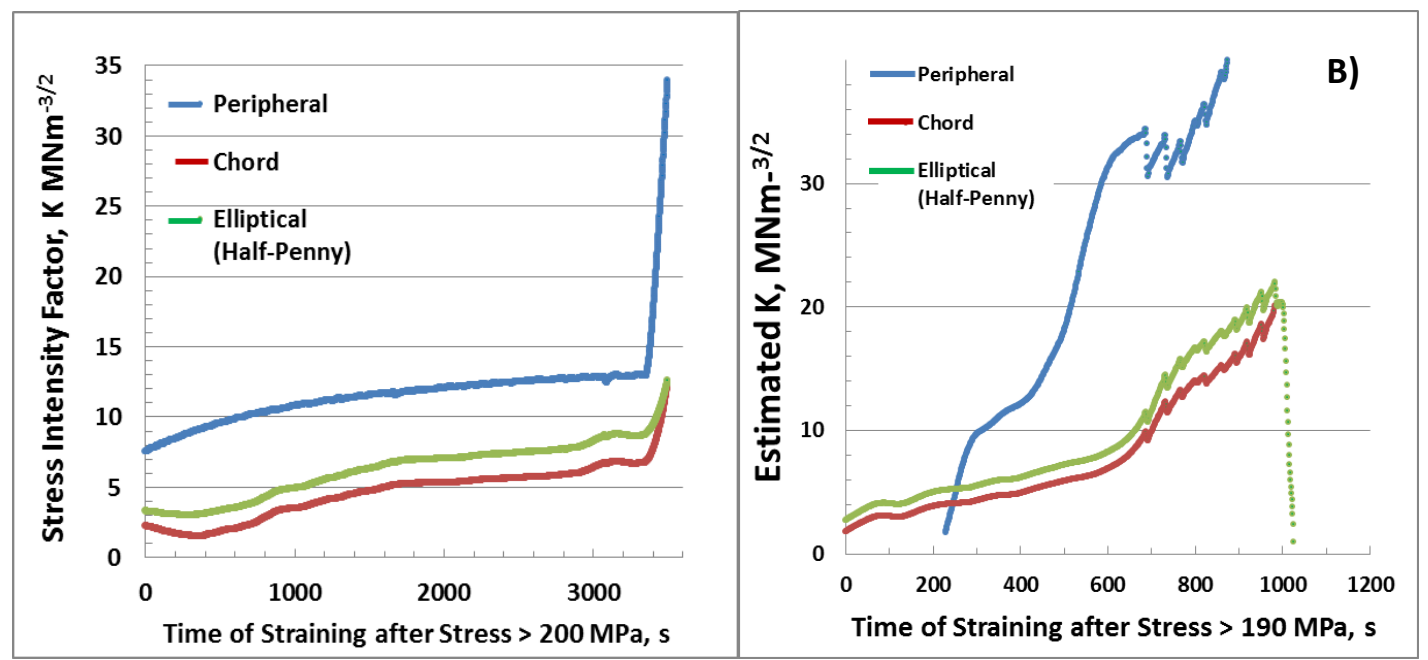

Figure 6: Predicted stress intensity factors for different crack geometries associated with EIC during the SSRT of as-received and sensitized AA5083- $\mathrm{H} 131$ pre-exposed to $0.6 \mathrm{M} \mathrm{NaCl}$ and strained in humid air at a nominal strain rate of $10^{-5} / \mathrm{s}$. A) As-received $+375 \mathrm{hr}$ pre-exposure to $0.6 \mathrm{M} \mathrm{NaCl}$ and B) Sensitized $250 \mathrm{hr} 80^{\circ} \mathrm{C}+250 \mathrm{hr}$ in $0.6 \mathrm{M}$ $\mathrm{NaCl}$.

CV-K curves, Figure 7, are obtained using data provided in Figures 5 and 6.

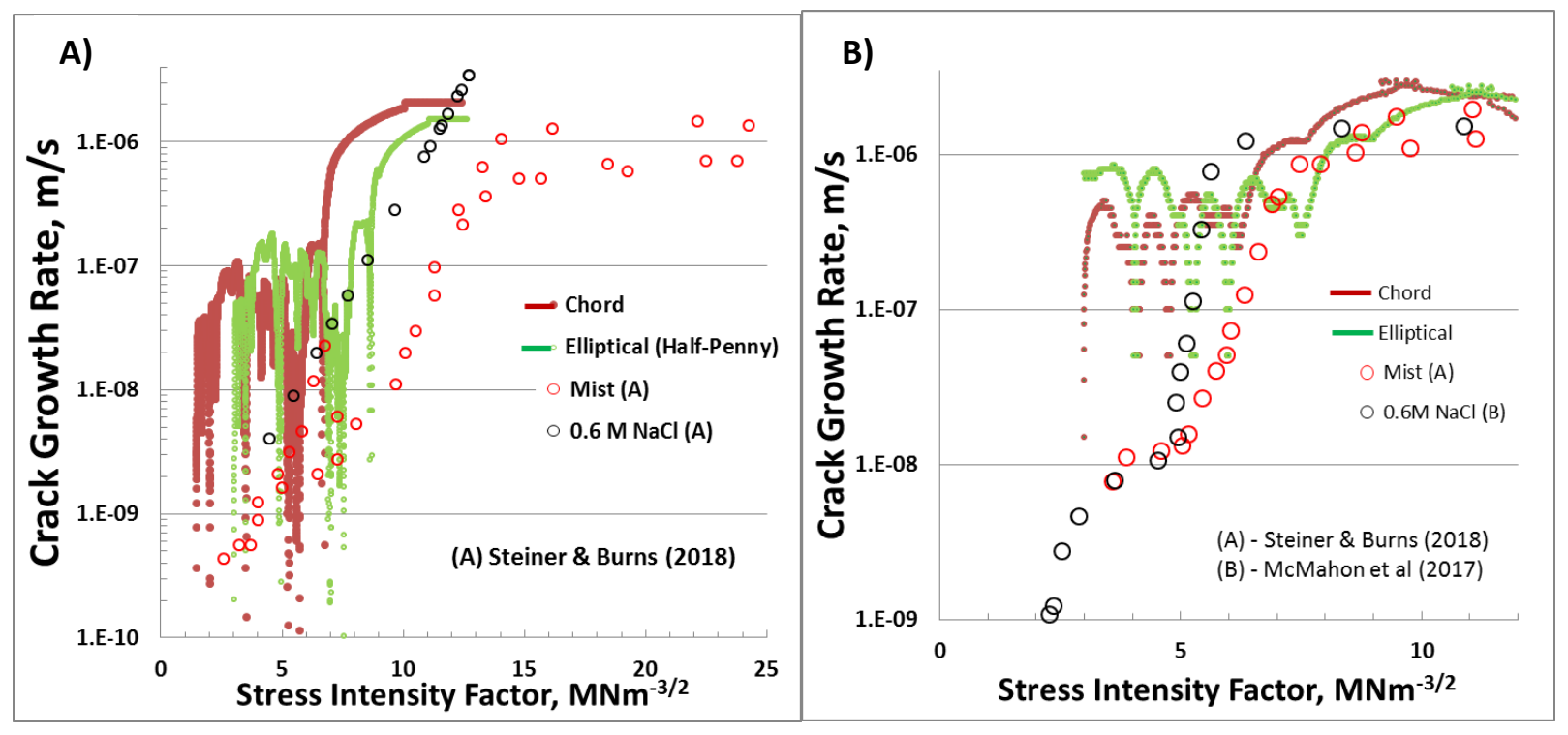

Figure 7: Predicted CV-K behaviour (assuming different geometries) promoted during the SSRT of as-received and sensitized AA5083-H131 pre-exposed to $0.6 \mathrm{M} \mathrm{NaCl}$ and strained in humid air at a nominal strain rate of $10^{-5} / \mathrm{s}$. A) As-received $+375 \mathrm{hr}$ pre-exposure to $0.6 \mathrm{M} \mathrm{NaCl}$ and B) Sensitized $250 \mathrm{hr} 80^{\circ} \mathrm{C}+250 \mathrm{hr}$ in $0.6 \mathrm{M} \mathrm{NaCl}$. CV-K curves from literature $(A, B)$ provided for comparison.

\section{Discussion}


Subjecting AA5083- $\mathrm{H} 131$ tensile specimens to pre-exposure in $0.6 \mathrm{M} \mathrm{NaCl}$ ahead of SSRT led to simultaneous hydrogen pre-charging and localized intergranular corrosion (IGC) providing local stress raisers, arguably transforming the originally smooth tensile specimens into pseudo precracked test specimens but with little associated plasticity. This enables EIC initiation in humid air at considerable higher nominal strain rates than those required without pre-exposure (Holroyd et al., 2017 a, b).

The agreement between maximum predicted EIC depths, obtained from analysis of loadextension data obtained during SSRT, Figure 8, and those observed on the fracture surfaces of failed SSRT tensile samples, Figure 9, for both the as-received and sensitized AA5083-H131 is remarkable, particularly considering our assumption to attribute loading-bearing area losses during SSRT to a single region of EIC, when its evident multiple EIC cracks have initiated during SSRT and several typically contribute to SSRT failures, Figure 9.

A)

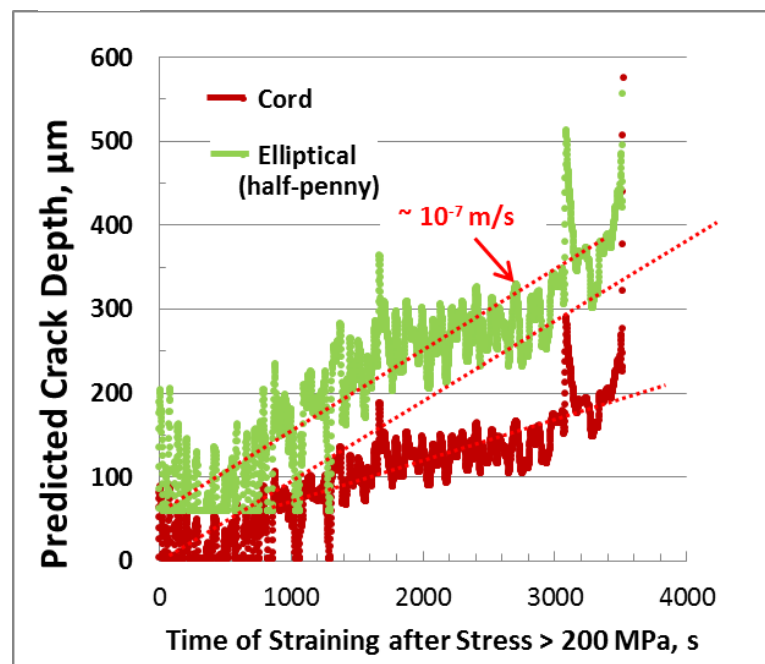

B)

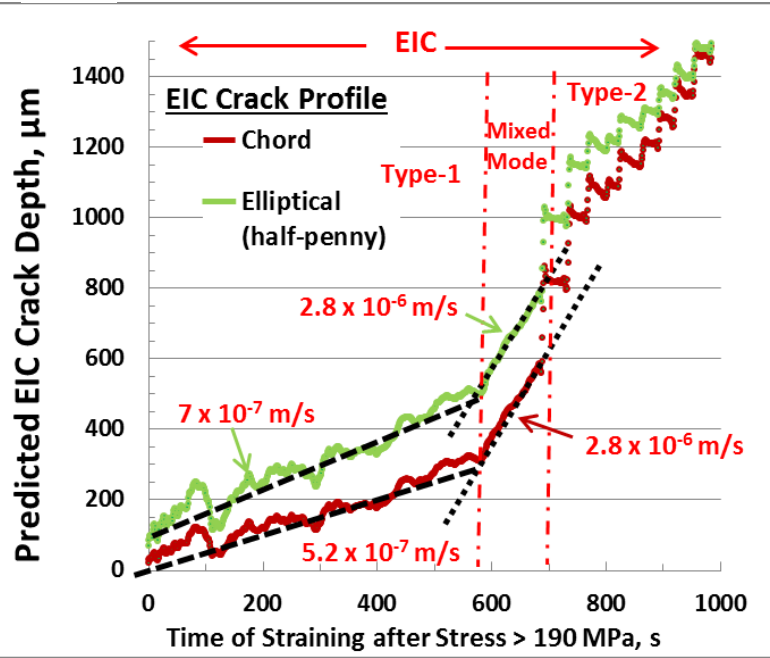

Figure 8: Predicted EIC depths for different geometries in AA5083 using load-extension data obtained during the SSRT of as-received and sensitized AA5083- $\mathrm{H} 131$ pre-exposed to $0.6 \mathrm{M} \mathrm{NaCl}$ and strained in humid air at a nominal strain rate of $10^{-5} / \mathrm{s}$. A) As-received $+375 \mathrm{hr}$ pre-exposure to $0.6 \mathrm{M} \mathrm{NaCl}$ and B) Sensitized $250 \mathrm{hr} 80^{\circ} \mathrm{C}+250 \mathrm{hr}$ in $0.6 \mathrm{M} \mathrm{NaCl}$.

Predicted EIC growth rates for the sensitized AA5083-H131 display a sudden increase when EIC depths exceed $\sim 580 \mu \mathrm{m}$, Figure $8 \mathrm{~B}$, whereas no such increase was obvious for the as-received material, Figure $8 \mathrm{~A}$. It is interesting to note in harmony with these predictions, fracture mode evaluation during SSRT indicates the sensitized material underwent an EIC mode transition, from solely Type-1 EIC to a mixed mode involving Type-1 and Type-2 EIC, when EIC depths exceeded $\sim 580 \mu \mathrm{m}$, Figure 9B, whereas limited Type-2 EIC was detected in as-received material.

A more detailed comparison of the predicted and experimentally observed EIC behavior promoted during our SSRT of AA5083-H131 in humid air after pre-exposure to $0.6 \mathrm{M} \mathrm{NaCl}$ is provided in Table 2, from which it is apparent the predicted EIC depths are slightly lower than those observed experimentally. This difference we attribute to multiple EIC crack initiation and 
crack coalescence during SSRT, the results of which are apparent in the fracture surfaces shown in Figure 9.

Despite these differences our initial findings indicate the accelerated test method presented here should be capable of quickly providing, an indication of an aluminum alloys EIC threshold stress intensity factor, $\mathrm{K}_{\mathrm{IEI}}$, and its potential EIC susceptibility as a function of alloy sensitization/temper.

Table 2: Comparison of predicted and experimentally observed EIC characteristics promoted during the SSRT of as-received and sensitized AA5083-H131 in humid air (50\% RH) after pre-exposure to $0.6 \mathrm{M} \mathrm{NaCl}$.

\begin{tabular}{|c|c|c|c|c|}
\hline & \multirow{2}{*}{$\begin{array}{c}\text { Observed } \\
\text { (Holroyd et al., } \\
\text { 2000) } \\
\text { Type 1-EIC }\end{array}$} & \multicolumn{2}{|c|}{ Predictions using SSRT data } \\
\hline & & & Type 1-EIC & Type-2 EIC \\
\hline \multirow{3}{*}{$\begin{array}{c}\text { As- } \\
\text { Received }\end{array}$} & Depth, $\mu \mathrm{m}$ & 500 & 400 & $400-500$ \\
\hline & $\mathrm{CV}(\mathrm{m} / \mathrm{s})$ & --- & $\sim 10^{-7}$ & $>10^{-7}$ \\
\hline & $\mathrm{K}\left(\mathrm{MN}^{-3 / 2}\right)$ & $3.8-11.3$ & $>3-9$ & $>9$ \\
\hline \multirow{3}{*}{ Sensitized } & Depth $(\mu \mathrm{m})$ & 890 & $\begin{array}{c}580 \\
580-700 *\end{array}$ & $700->1500$ \\
\hline & $\mathrm{CV}(\mathrm{m} / \mathrm{s})$ & --- & $\begin{array}{c}\sim 7 \times 10^{-7} \\
\sim 2.8 \times 10^{-6} *\end{array}$ & $\begin{array}{c}\text { Numerous } \\
\text { sudden jumps } \\
\text { (Av. CV } \\
\sim 2.8 \times 10^{-6}\end{array}$ \\
\hline & $\mathrm{K}\left(\mathrm{MN}^{-3 / 2}\right)$ & $4.2-12.4$ & $\begin{array}{c}3-8 \\
8-11 *\end{array}$ & $>11.0$ \\
\hline
\end{tabular}

*Mixed mode Type-1 and Type-2 EIC 


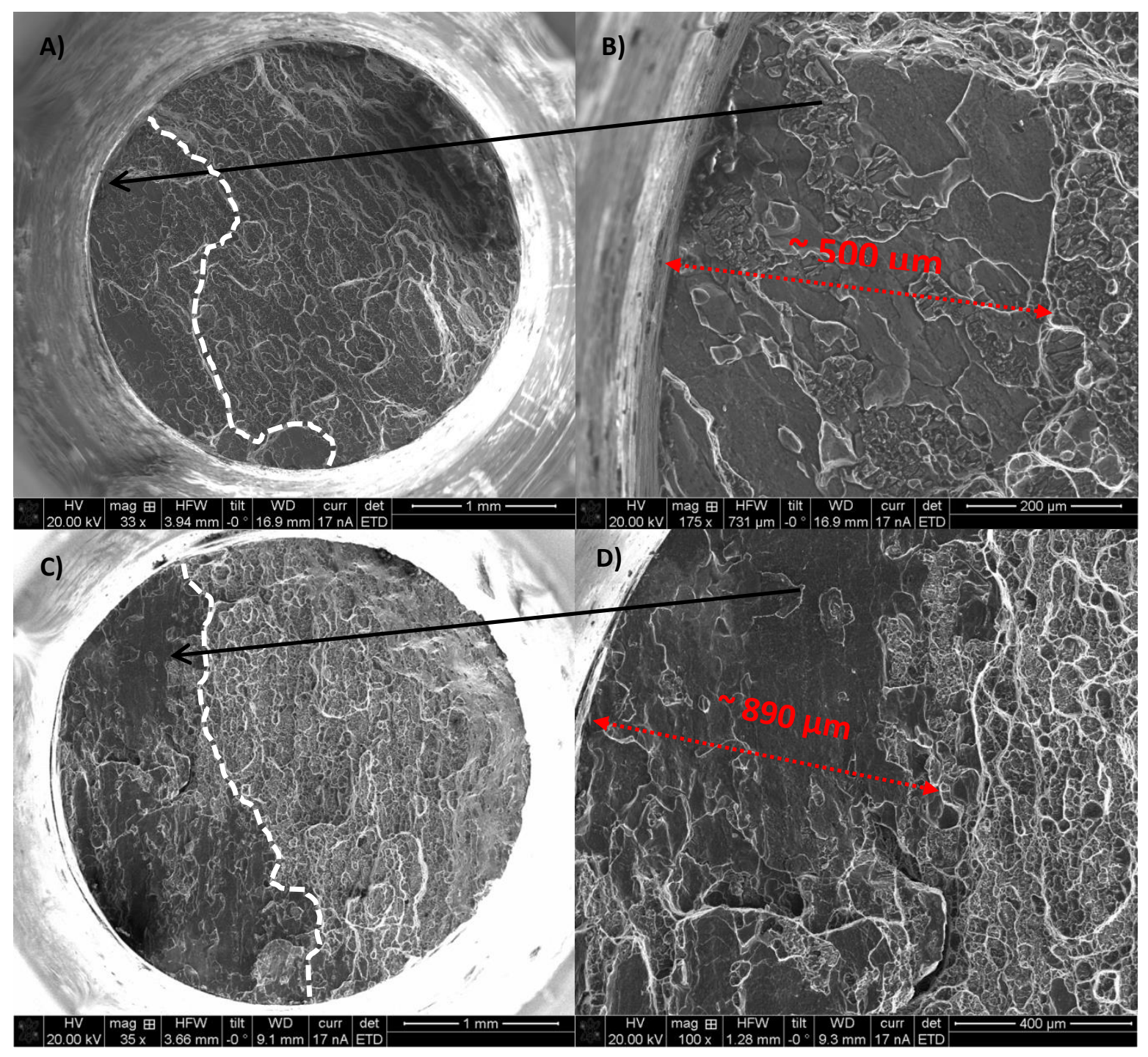

Figure 9: SEM images of fracture surfaces of SSRT samples strained to failure in humid air ( $50 \% \mathrm{RH})$ at a nominal strain rate of $10^{-5} / \mathrm{s}$. A) AA5083-H131 as-received $+375 \mathrm{hr}$ in $0.6 \mathrm{M} \mathrm{NaCl}$ (Test \# 4C) A) AA5083-H131 $+250 \mathrm{hr} 80^{\circ} \mathrm{C}$ $+375 \mathrm{hr}$ in $0.6 \mathrm{M} \mathrm{NaCl}$ (Test \#7); B) and D) are higher magnifications of A) and C) respectively.

Perhaps the most significant evidence for our assertion that the CV-K characteristics for AA5083-H131 may be acquired in this way is provided by:

a) A recent 3D Tomography time-lapse study on the SSRT of pre-exposed sensitized AA5083H131 material used here (Gudla et al, 2019) which confirms Type-1 EIC initiation is typically associated with IGC stress raisers and occurs when stress levels exceed $\sim 200 \mathrm{MPa}$ with initial EIC growth predominantly evolving as a half-penny shaped elliptical cracked region and $b$ ) reasonable agreement exists between the predicted CV-K behaviour and that reported for AA5083-H131 in similar tempers obtained using state-of-the-art fracture mechanics based testing equipment (Steiner \& Burns, 2018), Figure 7.

\section{Conclusions}


1) An accelerated test method which can provide crack growth rate (CV) as a function of the applied stress-intensity factor (K), (i.e. the CV-K behaviour) of EIC using slow strain rate testing is presented for as-received and sensitized AA5083-H131.

2) Predicted CV-K behaviour closely resembles published experimental data obtained using sophisticated fracture-mechanics based test methods.

3) The new approach employs a pre-exposure treatment ahead of straining to pre-charge tensile test specimens with hydrogen, while simultaneously introducing local intergranular corrosion sites to act as local stress raisers with limited associated local plasticity (i.e. 'chemical' pre-cracking) during SSRT.

4) Estimation of EIC areas promoted during SSRT as a function of time are calculated, assuming stress reductions between SSRT in humid and dry air after given plastic extension reflect a loss of load-bearing area, which is directly attributable to an area of EIC.

5) 3D time-lapse tomography studies of AA5083-H131 with identical sensitization, pre-exposure and SSRT conditions reveals confirms assumptions made on EIC initiation conditions and EIC growth for stress intensity factors up to around $15 \mathrm{MNm}^{-3 / 2}\left(\sim 50 \mathrm{~K}_{\mathrm{IC}}\right)$.

Acknowledgements: This work was carried out with the support of the Diamond Light Source, instrument I13 (proposal MT18165-1). Funding for BP and JJL were provided by ONRN00014-17-1-2573 and ONR-N00014-18-1-2608 along with the Arthur P Armington Professorship (JJL) at CWRU.

\section{References}

ASTM Standard E 1681-95, Standard Test Method for Determining a Threshold Stress Intensity Factor for Environmentally Assisted Cracking of Metallic Materials under Constant Load. In: ASTM Standard E 1681, Philadelphia: ASTM International 1995.

Burnett TL, Holroyd NJH, Lewandowski JJ, Ogurreck M, Rau C, Kelley R, Pickering EJ, Daly M, Sherry AH, Pawar S, Slater TJA, Withers PJ. Degradation of metallic materials studied by correlative tomography. In: $38^{\text {th }}$ Riso International Symposium on Materials Science, IOP Conf. Series: Materials Science and Engineering, 219, 012001: 2017.

Carpinteri A. Elliptical-arc surface cracks in round bars. Fatigue Fract. Mater. 1992; 15: 1141-1153.

Domack MS. Evaluation of K1SCC and da/dt Measurements for Aluminum Alloys using Precracked Specimens. In: Lisagor WB, Crooker TW, Leis BN, editors. Environmentally Assisted Cracking: Science and Engineering. Philadelphia, PA: ASTM STP 1049, 1990: 391-409. 
Dietzel W. Characterization of Susceptibility of Metallic Materials to Environmentally Assisted Cracking. In: GKSSForschungszentrum GmbH, Geesthacht Report GKSS 99/E/24: 1999.

Dietzel W. Standardization of Rising Load/Rising Displacement Testing. In: Kane RD editor. Environmentally Assisted Cracking: Predictive Methods for Risk Assessment and Evaluation of Materials, Equipment and Structures. West Conshohocken, PA: ASTM STP 1049, 2000: 317-326.

Dietzel W; Mueller-Roos J. Methods for Investigating and Testing - Experience with Rising Load/Rising displacement Stress Corrosion Cracking Testing. Materials Science 2001; 37(2): 264-271.

Gudla VC, Garner A, Palmer BC, Storm M, Lewandowski JJ, Withers PJ, Holroyd NJH, Burnett TL. Initiation and short crack growth behaviour of environmentally assisted cracks in AA5083-H131 investigated correlatively across time and length scales'. Corrosion Reviews 2019; ??: XX-XX.

Holroyd NJH; Hardie D. Effect of Inherent Defects on initiation of Stress Corrosion Cracking in weldable Al-Zn-Mg Alloys. Metals Technology 1982; 9: 229-234.

Holroyd NJH, Burnett TL, Seifi M, Lewandowski JJ (a). Improved understanding of environment-Induced cracking (EIC) of sensitized 5XXX series aluminum alloys. Mat. Sci and Eng. A 2017; 682: 613-621.

Holroyd NJH, Burnett TL, Seifi M, Lewandowski JJ (b). Pre-Exposure embrittlement of a commercial Al-Mg-Mn alloy. AA5083-H131. Corrosion Reviews 2017; 35 (4-5): 275-290.

Holroyd NJH, Scamans GM. Stress Corrosion Cracking of Al-Zn-Mg-Cu Aluminum Alloys in Saline Environments. Metallurgical and Materials Transactions A 2013; 44A: 1230-1253.

Hyatt MV. Use of Precracked Specimens in Selecting Heat Treatments for Stress Corrosion Resistance in High Strength Aluminum Alloys. In: Boeing Commercial Airplane Document DC-224467. Seattle, OR: 1969.

Hyatt MV. Effects of Specimen Geometry and Grain Structure on SCC behavior of Aluminum Alloys. In: Boeing Commercial Airplane Document D6-24470. Seattle, OR: 1969.

Hyatt MV. Use of precracked specimens in stress corrosion cracking testing of high strength aluminium alloys. Corrosion 1970; 26: 487-503.

ISO 7539-6, ISO Standard on Corrosion of Metals and Alloys - Stress Corrosion Testing; Part 6: Pre-cracked Specimens. Geneva, Switzerland: International Organization for Standardization: 1998.

Kaufman JG, Coursen JW, Sprowls DO. An Automated Method for evaluating Resistance to Stress Corrosion Cracking wit Ring-Loaded Precracked Specimens. In: Craig HL, editor. Stress Corrosion- New Approaches. Philadelphia: ASTM STP 610, 1976: 94-107.

McMahon ME, Steiner PJ, Lass AB and Burns TJ. The Effect of Temper and Composition on Stress Corrosion of AlMg Alloys. Corrosion 2017; 73: 347-361.

McNaughtan D, Worsfold M, Robinson MJ. Corrosion product force measurements in the study of exfoliation and stress corrosion cracking in high strength aluminium alloys, Corrosion Science 2003; 45: 2377-2389.

Mulherin JH. Influence of Environment on Crack Propagation Characteristics of High-Strength Aluminum Alloys. In: Stress Corrosion Testing. Philadelphia: ASTM STP 425, 1967: 66-81. 
Seifi M, Holroyd NJH, Lewandowski JJ. Deformation Rate and Sensitization Effects on Environmentally Assisted Cracking of Al-Mg Naval Alloys. Corrosion 2016; 72: 264-283.

Schra L, Faber J. Influence of Environments on Constant Displacement Stress Corrosion Crack Growth in High Strength Aluminium Alloys, In: National Aerospace Laboratory, Holland: 1981: Report NLR-TR 81138U

Shih YS, Chen JJ. The stress intensity factor study on an elliptical cracked shaft. Nucl. Eng. Design 2002; 214: 137145.

Speidel MO, Hyatt MV. Stress Corrosion of High-Strength Aluminum Alloys. In: Advanced Corrosion Science Technology, vol. 2. Plenum Press, New York 1972: 115-335

Speidel MO. Stress Corrosion of Aluminum Alloys. Metallurgical Transactions A 1975; 6A: 631-651.

Sprowls DO, Shumaker MO, Walsh JD, Coursen JW. In: Evaluation of Stress Corrosion Cracking Susceptibility using Fracture Mechanics Techniques. George C Marshall Space Flight Center, Alabama, Final Report Contract NO. NAS8021487, 1973: Part 1.

Sprowls DO, Coursen JW, Walsh JD, Evaluating Stress-Corrosion Crack-Propagation in High-Strength Aluminum Alloys with Bolt loaded Precracked Double-Cantilever-Beam Specimens. In: Craig HL, editor. Stress Corrosion- New Approaches. Philadelphia: ASTM STP 610, 1976: 143-156.

Sprowls DO, Bucci RJ, Ponchel BM, Brazil RL, Bretz PE. In: A Study of Environmental Characterization of Conventional and Advanced Aluminum Alloys for Selection and Design - Phase II - The Breaking Load Method. NASA Langley Research Center, Hampton, VA, NASA Contract NASI-116424 Report No. 172397: 1984

Stark HL, Ibrahim RN. Estimating Fracture Toughness from Small Specimens. Engineering Fracture Mechanics 1986; 25: $395-401$.

Stark H, Ibrahim RN. Validity Requirements for Fracture Toughness Measurements Obtained from Small Circumferentially Notched Cylindrical Specimens. Engineering Fracture Mechanics, 1987; 28: 455-460.

Steiner PJ, Burns TJ. Mechanistic Studies of Intergranular Stress Corrosion Cracking in Al-Mg Alloys under Atmospheric Conditions, Corrosion 2018: 1117-1131.

Willard HH, Smith GF. The preparation and properties of magnesium perchlorate and it use as a drying agent. J. Am. Chem. Soc. 1922; 44: 2255-2259. 